GLOBAL JOURNAL OF EDUCATIONAL RESEARCH VOL 19, 2020 67-78

COPYRIGHT@ BACHUDO SCIENCE CO. LTD PRINTED IN NIGERIA. ISSN 1596-6224

67 www.globaljournalseries.com; Info@globaljournalseries.com

\title{
MONITORING AND CONTROL SKILLS OF HEADS OF SCIENCE DEPARTMENT AND ACADEMIC PERFORMANCE IN SCIENCES IN PUBLIC SECONDARY SCHOOLS IN NANDI COUNTY KENYA
}

ALFRED CHERUIYOT, JOASH K. KIBETT AND VIVILINE NGENO

(Received 8, November 2019; Revision Accepted 18, December 2019)

\begin{abstract}
This paper looks at the monitoring and control skills of Heads of Department (HODs) of science and its influence on academic performance by students in Kenya Certificate of Secondary Education Subjects. The HODs have been mandated to provide instructional guidance through regular monitoring, assessment and evaluation of science teaching subjects in their secondary schools. However, recent performances in science subjects (Biology, Chemistry and Physics) in KCSE in public secondary schools in Nandi County have been below average. Therefore, the objective of this paper was to determine the influence of science HODs monitoring and control skills towards academic performance of students in science subject. The study used mixed method research methodology which combined qualitative and quantitative data. The area of study was all public secondary schools in Nandi County. Target population consisted of 231 HODs of science, 231 principals and 693 science subject teachers. The study adopted a mixed method research design. A sample size of 23 principals, 128 HODS of science and 247 science teachers were selected through stratified random sampling technique. Data was collected using questionnaires (for HODs and teachers) and interview guide (for principals). The reliability values for HODs was 0.795 and science teachers 0.775 which were above the threshold of $\mathrm{R}=0.7$. Analysis of data was performed using quantitative and qualitative methods. Results of the analysis revealed that HODs organising regular departmental meetings to review performance and take corrective action where possible was the main monitoring and control used. On the average, the study discovered that HODs of science planed with science teachers evaluation and assessment activities in their schools $(M=3.38$ and $S D=1.25)$. The paper concludes that there existed a significant positive influence $(p<0.05)$ between HODs of Science monitoring and control skills and academic performance of students in science subjects in selected public secondary schools in Nandi County, Kenya. It was recommended that Teachers Service Commission needs to improve staffing levels in public secondary schools especially in science subjects to in order provide ample time for HODs to do their regular monitoring and control activities of science subjects' curriculum implementation in classrooms and among their departmental teachers.
\end{abstract}

KEYWORDS: Science, Monitoring, Control, Performance and Assessment

INTRODUCTION

Science is an important discipline across the world since time immemorial, today and future.
Science education is a vital tool for individual and societal development (Bichi, Hafiz, Abdulahi, 2017). This is because it builds and organises

Alfred Cheruiyot, Department of Educational Administration, Planning and Management,

University of Kabianga, Kenya

Joash K. Kibett, Department of Horticulture (Agricultural Education), University of Kabianga, Kenya

Viviline Ngeno, Department of Educational Administration, Planning and Management, University of Kabianga, Kenya

(ㄷ) 2020 Bachudo Science co. Ltd. This work is Licensed Under Creative Commons Attribution 4.0 international license. 
knowledge in the form of testable explanation and prediction concerning the universe (Rono, 2017). This means that science is a body of knowledge by itself which can be rationally explained or reliably applied. This means that learning science subjects in schools is significant to individuals and the society at large. All countries across the world have included science subjects in their basic and also higher education curriculum including Kenya. This has seen emphasis being encouraged for all students to perform better in sciences; Biology, Chemistry and Physics. Bichi et al. (2017) indicates that the three subjects are mainly provided separately when students join secondary schools. In addition, the pass rate of students at this level forms one of the main requirements for their admission to study science, engineering, agriculture, technology and other related courses in tertiary institutions. Hence, for improved performance, instructional guidelines have to be enforced at school and those tasked with the responsibility are heads of department. Therefore, Heads of Department (HODs) of sciences are positioned as instructional leaders. Review of policies from different countries shows that they assist teachers in attaining their professional and personal goals associated with curriculum and also to monitor whether the said goals are successfully achieved a concept under this paper; monitoring and control. In addition, the HODs of sciences are supposed to conduct regular formal and informal classroom observation with the purpose of providing direction to teachers on the best possible methods of ensuring curriculum goals are attained (Seobi \& Wood, 2016).

A review of performance by students in science subjects across several countries in sub Saharan Africa shows a decline in performance. Bichi et al (2017) study in Nigeria showed persistent low levels of students' achievement in sciences at the various public examinations have been the norm. In South Africa, Zenda (2016) found out that high failure rate by students undertaking physical sciences subjects among rural secondary schools. In Namibia, Muyoyeta, Abah and Denuga (2017) discovered that Grade 12 learners' academic performance in the Namibia Senior Secondary Certificate Ordinary level (NSSCO) Biology subject was very low. In Kenya, Rono (2017) analysis of Bomet County 2013 KCSE showed that out of the 20 subjects that the candidates sat for, physics was position 17. This shows a discouraging trend across various Sub Saharan African countries particularly in science performance. Nevertheless, research investigating the influence of HODs of science monitoring and control skills towards academic performance in the subjects is limited. This is because Rono (2017) focused on the effect of laboratory management whereas Muyoyeta et al. (2017) research focused on school based factors. The lack of adequate literature on how HODs of sciences monitoring and control skills influenced performance created a research gap that this paper intended to fill.

\section{STATEMENT OF THE PROBLEM}

When HODs perform their instructional and management roles in monitoring and control, performance of students in science subjects would improve. However, analysis of KCSE data (2013-2017) for the three science subjects in Nandi County showed that they performed below the National mean scores for the 5 years in the respective science subjects. Biology performance had been on the decline for the five years under study and across the years, the national mean score was above the county mean score. Despite the massive investment by government of Kenya through provision of teaching learning materials, establishment of laboratories in some public secondary schools across the country and capacity building among science teachers through SMASSE country wide, it is evident that majority of schools are still performing dismally in science subjects. It is due to the above reason that the paper investigated the influence of HODs monitoring and control skills on academic performance of students in KCSE science subjects in public secondary schools in Nandi County, Kenya.

\section{LITERATURE REVIEW}

Monitoring and Controlling constitutes a management process through which HODs of Science ensure by means of assessing and regulating, that teaching and learning is in progress, and thus the school's outcomes may be accomplished (Bennett \& Woods, 2007). This is to verify that all activities are in line with the policy and that instructions are being carried out. As part of the management team, HODs of Science should keep abreast of the latest schools of thought on approaches, methodology, techniques, and evaluation. Given that their work is linked directly to the teachers in their departments, they should have an interest in them. Focusing on teaching and learning, HODs of Science must be familiar with the following 
formal methods of Science of control, as set out by van Deventer and Kruger (2003): Preparation: Encourage teachers to prepare their lessons in writing so that they can be checked to gauge their knowledge of the subject. This will ensure that they do not come to class unprepared. Presentation: Class visits can be used to gauge the success of a teacher's presentation of a lesson, thus encouraging professional growth and providing support. Evaluation: In order to check whether the teachers' evaluation is up to standard, the question papers, memoranda and answer papers of tests and examinations must be presented to the HODs of Science for moderation. Formal meetings: HODs of Science should utilize subject meetings to measure teachers' knowledge and skills in the subject. If this seems lacking, these meetings can also serve as corrective measures for improving the quality of teaching.

According to van Deventer and Kruger (2003), a monitoring system will indicate to HODs of Science, whether activities are proceeding according to plan; if something unexpected has happened that might have influenced the plan; and if the situation has changed completely, whether or not they will have to devise a new plan. However, van Deventer and Kruger overlooked the actual problems HODs of Science experience with controlling. Teachers do not cope with demands upon them, such as changes to the curriculum, conditions of service, and the ever-broadening role of the teachers (Dean, 2002). These problems have an effect on motivation levels, which may thus hamper performance (Foskett \& Lumby, 2003). Various research studies have been done across several countries to check on the issue of monitoring control influence on academic performance of students in secondary schools. In South Africa, Shonubi (2014) compared two schools in relation to how effective leadership functions (instructional and transformational leadership) may have been utilized to arrive at differential academic outputs in schools. Utilizing the qualitative research approach, data was collected from internal key role players (otherwise referred to School Leadership Team [SLT]) from two selected schools: one exceptional performing and the other, underperforming. Findings indicated that monitoring, modeling, and internally funded training and development of teachers, ensured effective instructional delivery and up to date knowledge in the teaching skills; and subject knowledge update of teachers in the exceptionally performing school, which impacted on student's performance in the exceptionally performing school, compared to the exceptionally underperforming school.

Malinga (2016) indicated that Natural Sciences (NS) HODs of Science in schools often find themselves in the middle, shuttling between a role in the management of the school and another as ordinary classroom teachers. The study uses mixed methods of Science research approach with questionnaires, semi-structured interviews and observation of subject department meetings as data sources to understand the realities of providing subject leadership for NS in selected schools within the Gauteng province of South Africa. Most science HODs of Science do not teach NS and/or do not have the instructional experience needed for all the sub-disciplines under their leadership. Some are not adequately qualified to teach NS at all and/or do not have the subject matter competency, the Pedagogical Content Knowledge (PCK), or the professional credibility to lead NS instruction. As a result, they often resort to monitoring instruction through desk-top reviews of teachers' and students' work rather than conduct any meaningful classroom observations or spend time discussing curriculum issues with the teachers. Niyivuga, Otara and Tuyishime (2019) determined the relationship between Monitoring and Evaluation (M\&E) practices and academic staff motivation in higher education, from a Rwandan perspective. The study employed mixed-methods of Science approach to collect data from academic staff. A total of 105 faculties were sampled. The study established that M\&E practices, including staff self-evaluation, students staff evaluation, peer evaluation, and evaluation by supervisors, are applied at varying degree of emphasis.

Gramme and Naidoo (2011) stipulated that " in a global economy monitoring and evaluation of students achievement is changing because in an ever dynamic knowledge based society, students would not be required to learn and understand the basics but also think critically, to analyze and make inferences for further decision making'. Monitoring and control is an integral part of management and an ongoing review process to ensure focus on the external factors to strengthen the rise of factual information for decision making, overcome threats and weaknesses, take advantage of opportunities and minimize the effects of threats. Monitoring and control is used as a tool for improving performance through understanding and 
comparing internal and external practices required to achieve performance targets. Ambula (2010) carried out a study on bench-marking and performance in public secondary schools in Nairobi, Kenya and revealed that most schools practice monitoring and control in areas such as discipline, parental involvement, motivation, leadership, teaching and learning resources which eventually affected performance in teaching and learning. However, the study did not mention the influence of monitoring and control skills on student academic performance in science subjects hence leaving a gap to be investigated on.

Nzoka and Orodho (2014) analyzed the strategies school managers apply to improve academic performance of students in schools under free day secondary school education in Embu District, Embu County, Kenya. A descriptive survey research design was adopted. A combination of purposive and stratified random sampling techniques were utilized to draw 54 members of the Board of Management (BoM), 45 heads of departments and 36 members of Parents Teachers Association (PTAs) yielding to a sample size of 135 subjects to participate in the study. It was established that school managers used various strategies to improve students' academic performance. The strategies included: inconsistent monitoring of instructional processes and student assessment. In Kenya, Opiyo (2014) study was to establish influence of budgeting on implementation of development plans in public secondary schools in Uriri District, Migori County. The study employed descriptive survey research design where the target population was 19 principals, 96 head of departments, 247 boards of governors and 19 bursars. Random sampling was used to pick the sample. On monitoring and evaluation on implementation of school development plans over 90\%, HODs of Science showed that monitoring and evaluation identify errors. Ndungu, Gathu and Bomett (2015) investigated the influence of monitoring and evaluation on effective teaching and learning in secondary schools in Githunguri district. The study adopted survey research design. The study targeted 30 principals, 750 teachers, 150 HODs of Science and 120 class prefects 1 class prefect per stream in the 30 public secondary schools in Githunguri district. They found out that there was no assessment of teachers teaching in classrooms, teacher's preparation of lesson plans and a scheme of work is not ensured in the majority of secondary schools in Githunguri district. The study indicated that teachers who prepare lesson plans are more effective than those who do not. The HOD do not regularly discuss with students about the content taught to the class. According to the management guidelines by the Teachers Service Commission (TSC), to be able to manage people, HOD's must have essential skills, which include high levels of decision-making and problem solving and not to forget communication skills especially when handling meetings in the departments. HOD, being a human resource and relations manager needs to have individual capacity to motivate others and to promote team spirit in the department. While teaching the subject of specialization in the department, the HOD should have effective instructional leadership and supervision skills and create an atmosphere that facilitates effective learning. This requires critical and creative thinking to maintain interactive learning in the department. Therefore, the study determined whether the HODs of Science had these skills as part of their responsibilities aimed at ensuring performance improvement in schools in Nandi County, Kenya.

\section{MATERIALS AND METHODS}

The study adopted a mixed method research design to investigate the influence of head of science departments' monitoring and control practices on students' academic performance in science subjects in Nandi County, Kenya. Mixed method design is an approach to inquiry that combines and associate both qualitative and quantitative forms (Ayiro 2012). This study was carried out in Nandi County, in the North Rift of Kenya. The county has six administrative Sub Counties namely; Emgwen, Mosop, Aldai, Nandi hills, Tinderet and Chesumei (Kenya National Bureau of Statistics (KNBS), (2013). , the target population consisted of 231 principals, 693 science teachers and 231 heads of science departments in 231 schools in Nandi County. The sample size was arrived through a statistical formular for sample size determination and the results are illustrated in Table 1.

Table 1: 


\section{SAMPLE SIZE PER CATEGORY}

\begin{tabular}{lllllll}
\hline Category & $\begin{array}{l}\text { Principals } \\
\text { Target (N) }\end{array}$ & $\begin{array}{l}\text { Sample } \\
(\mathbf{n})\end{array}$ & $\begin{array}{l}\text { HODs of Science } \\
\text { Target (N) }\end{array}$ & Sample (n) & $\begin{array}{l}\text { Teachers } \\
\text { Target (N) }\end{array}$ & Sample (n) \\
\hline National & 2 & 2 & 2 & 1 & 6 & 3 \\
Extra County & 4 & 2 & 4 & 2 & 12 & 3 \\
County & 60 & 5 & 60 & 33 & 180 & 66 \\
Sub County & 165 & 14 & 165 & 92 & 495 & 175 \\
Total & $\mathbf{2 3 1}$ & $\mathbf{2 3}$ & $\mathbf{2 3 1}$ & $\mathbf{1 2 8}$ & $\mathbf{6 9 3}$ & $\mathbf{2 4 7}$ \\
\hline
\end{tabular}

The principals, HODs and teachers were selected using stratified random sampling technique. The study used three research instruments to collect both quantitative and qualitative data namely: questionnaires, interview schedule and document analysis. Data collection was carried out by the researcher. Analysis of data was performed using descriptive; frequencies, percentages, means and standard deviation and inferential statistics; correlations.
Results are presented and discussions are presented below.

\section{RESULTS AND DISCUSSION}

HODs of Science and science teachers were asked to indicate the period to which they have been teaching in secondary schools (together with leadership time for HODs of Science). Their results are summarised in Table 2 .

Table 2 Work Experience of HODs of Science and Teachers of Science

\begin{tabular}{llllll}
\hline Experience & N & Min & Max & Mean & Std. Deviation \\
\hline HOD of science & 114 & 1.00 & 20.00 & 4.5789 & 3.27202 \\
Science teachers & 223 & 1.00 & 38.00 & 8.6188 & 7.63249 \\
\hline
\end{tabular}

Results show that the average number of working experience for HODs of Science of science was five years whereas for teachers it was 9 years. The result further depicts a relatively high standard deviation scores; HODs of Science $(S D=3.27)$ and science teachers $(S D=7.6)$ implying that teachers and HODs of Science working experience varied. The experience is important as it determines their competency in implementing science curriculum in schools. The findings agrees with Kweku et al. (2016) in a study conducted in Ghana where majority $58.8 \%$ had 2 to 7 years' experience followed by $29.4 \% 8$ who had 13 years' experience whereas only $11.5 \%$ had only 1 or less than 1 year experience. Contrary to the study results, Muyoyeta et al. (2017) in a study conducted in Namibia found out that more teachers and HODs of Science had more than 3 years teaching experience. As a result teachers are expected to be more effective in teaching Biology in secondary schools. 
The researcher also requested the HODs of Science of science to indicate the subject combinations that they taught in their schools. Their responses are given in Figure 1.

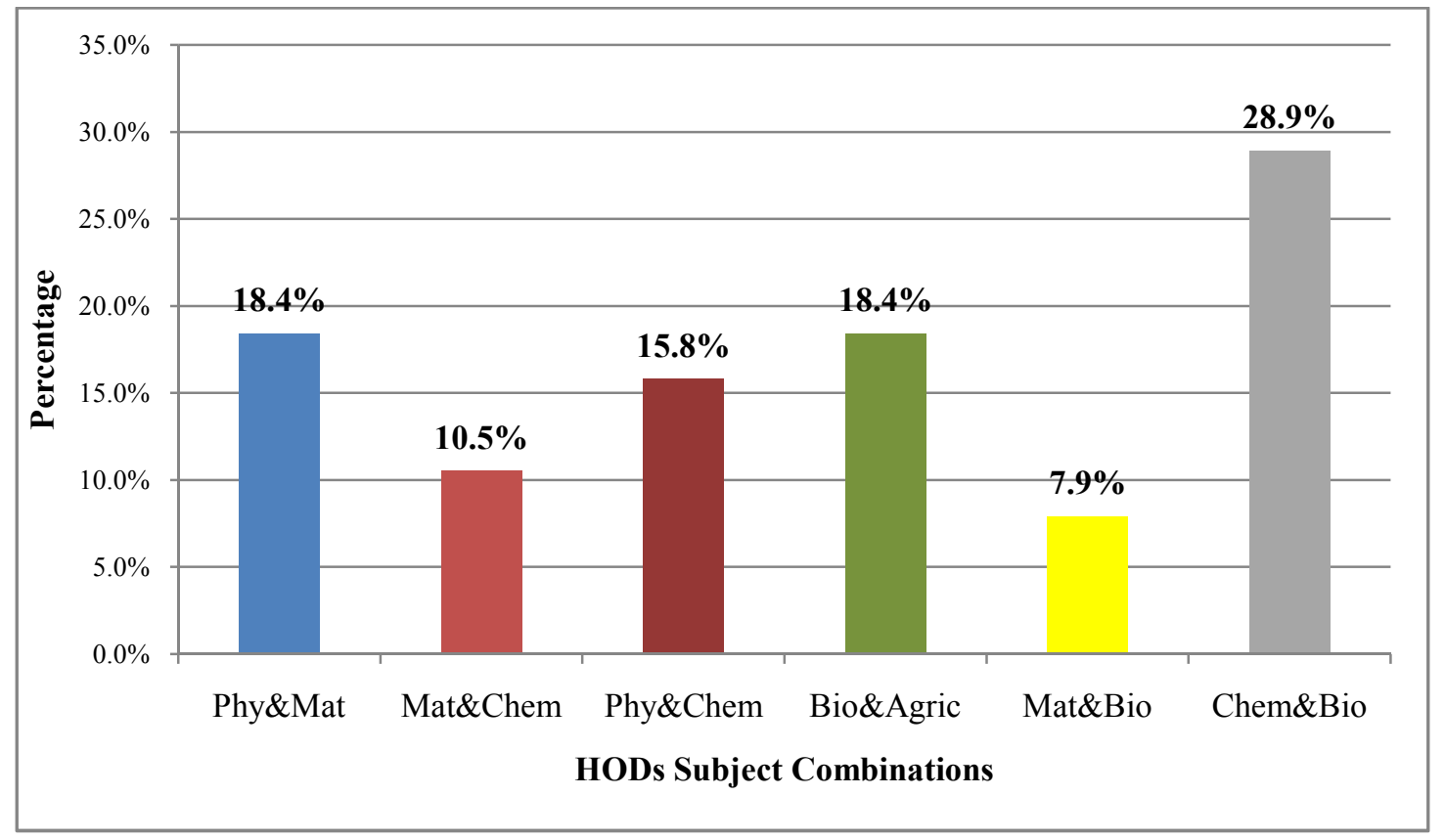

Figure 1 Teaching Subjects by HODs of Science Results depicts that HODs of Science possessed different combinations in teaching subject but majority $33(28.9 \%)$ were teaching Chemistry and Biology in their schools. This means that teachers combine the science subjects with others (agriculture, mathematics) that are related to them unlike combining with humanities. The science teachers too were asked to provide information with regard to their teaching subject combinations. The results are given in Figure 2.

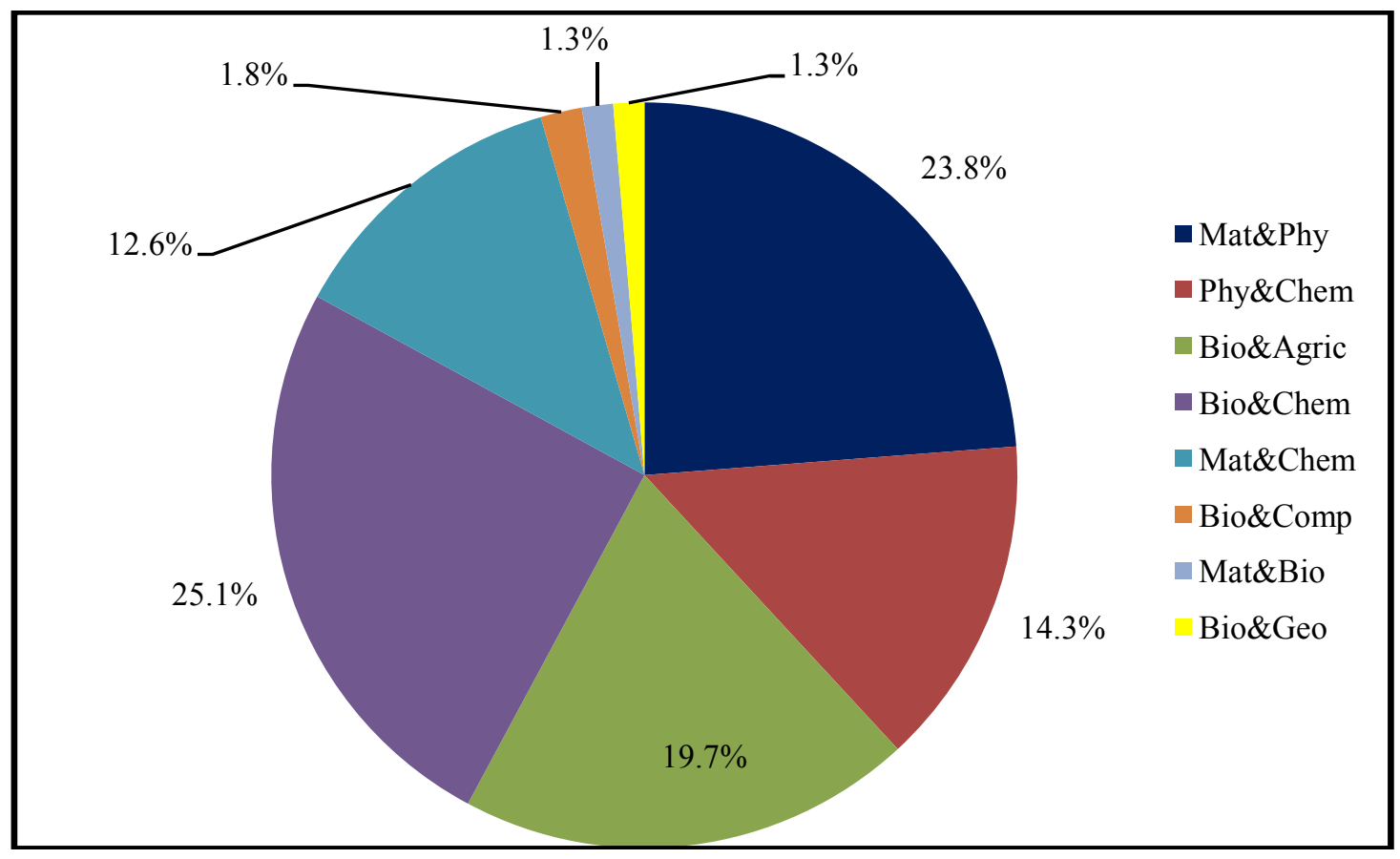

Figure: 2 Teaching Subjects Combinations by Science Teachers 
Research data depicts that for science teachers, $56(25.1 \%)$ taught Biology and Chemistry same as HODs of Science, $53(23.8 \%)$ taught Physics and Mathematics while $44(19.7 \%)$ taught Biology and Agriculture. The result depicts that the subject combination that teachers teach could influence the decision by students to adopt them in secondary schools. Further, Physics combination with other subjects is found to be are a less than $25 \%$ of teachers appear to be qualified and competent on the subject.
ACADEMIC PERFORMANCE OF SCHOOLS IN SCIENCE SUBJECTS

The dependent variable for this study was academic performance of schools in KCSE science subjects in the recent years. The study asked the HODs of Science of science to provide the average scores of their school in the last year KCSE examinations on the following subjects; Chemistry, Physics and Biology. The teachers were excluded because they did not have full information with regard to their performance in various science subjects. The results are given in Table

Table 3 Academic Performance of their Schools in KCSE Sciences Subjects

\begin{tabular}{lllll}
\hline School category & N & $\begin{array}{l}\text { Mean } \\
\text { Performance }\end{array}$ & Std. Deviation & Std. Error \\
\hline National & 1 & 9.5000 &. &. \\
Extra County & 2 & 7.1000 & .14142 & .10000 \\
County & 33 & 5.3636 & 1.39705 & .24320 \\
Sub County & 78 & 4.9782 & 1.47213 & .16669 \\
\hline Total/Average & $\mathbf{1 1 4}$ & $\mathbf{5 . 1 6 6 7}$ & $\mathbf{1 . 5 1 5 8 6}$ & .14197 \\
\hline
\end{tabular}

Result in Table 3 depicts that the performance of national schools was at $9.5(\mathrm{~B}+)$ with county schools recording a mean grade of achievement of $7.1(\mathrm{C}+)$, then county secondary schools at 5.36 (C-) and the least are sub county schools with an average of 4.97 (C-). The average mean score for the schools in KCSE science subjects (Biology, Physics and Chemistry) is 5.1 (C-) which is below average $(\mathrm{C})$.

Influence of Monitoring and Control Skills by HODs of Science and Academic Performance of Students in Science Subjects
The objective of the study was to determine the influence of monitoring and control skills by HODs of Science and academic performance of students in science subjects. To answer the objective, the study collected information from principals, HODs of Science and science teachers. Table 4 presents the descriptive results on the frequency to which HODs of Science rated their monitoring and skills in comparison to teachers' responses. The following scale was used; never (1.0-1.44), rarely (1.5-2.44), sometimes (2.5-3.44), often (3.5-4.44) and always

(4.5-5.0). 
Table 4: HODs of Science and Science Teachers Rating of Monitoring and Control Skills by HODs of Science in Secondary Schools

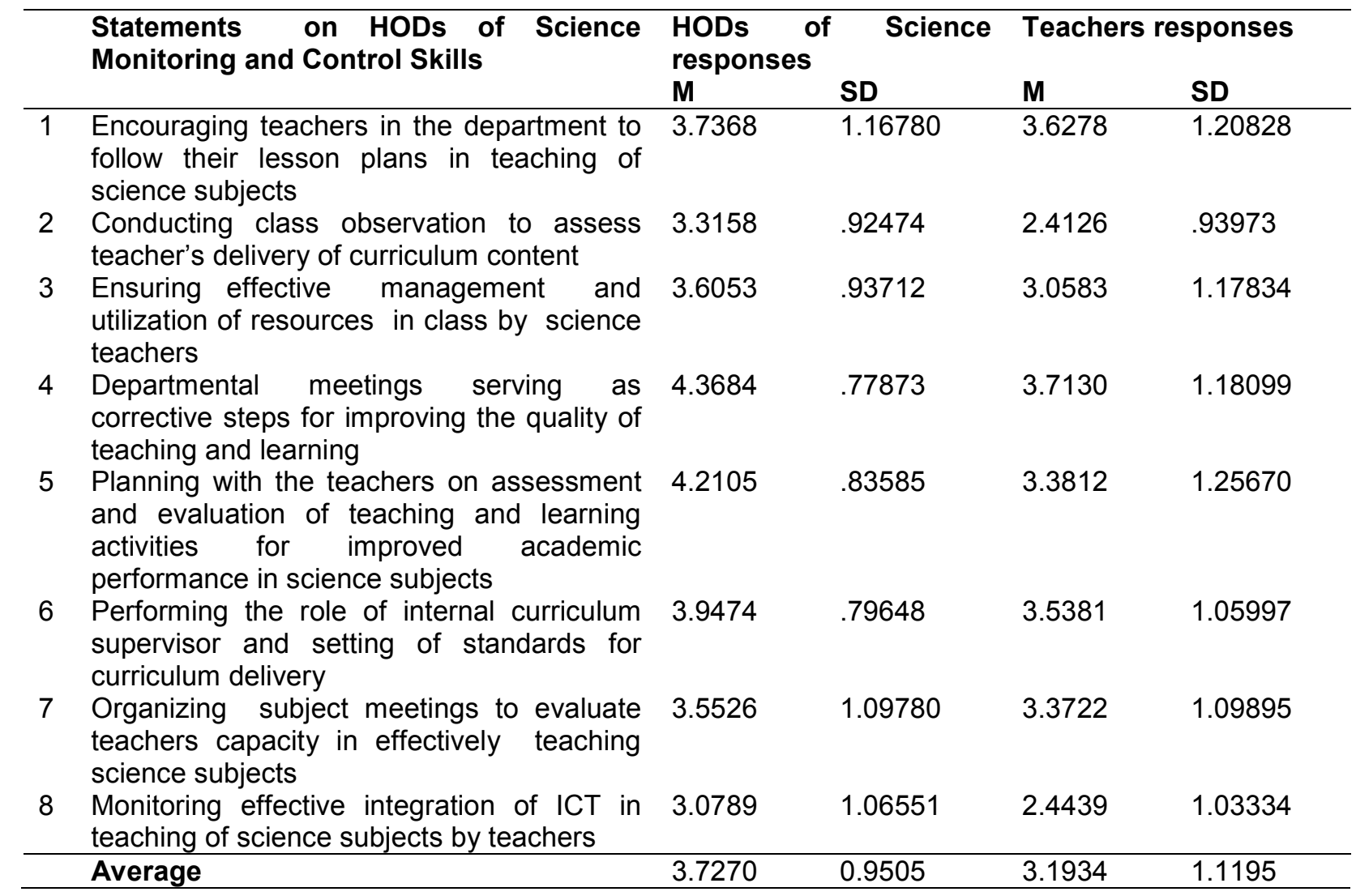

Findings of the study in Table 4 show that both HODs of Science $(M=3.73$ and $S D=1.17)$ and science teachers $(M=3.62$ and $S D=1.20)$ agreed that often do HODs of Science encourage teachers in their department to follow lesson plan during classroom learning. This means that majority of HODs of Science ensure that what is taught in class is what was indicated in the lesson plan documents. Secondly, results depicts that HODs of Science admitted that at times $(M=3.31$ and $S D=0.92)$ they do conduct classroom observation as part of monitoring what the teacher does during science lessons. However, teachers indicated that HODs of Science rarely $(M=2.41$ and $S D=0.93)$ perform classroom observation to assess the delivery of science subjects curriculum content. Inadequate number of science teachers in schools making it impossible for HODs of Science to have adequate time to conduct classroom observation compounds this problem. This information was supported by 20 out of 23 principals interviewed who said that there are no adequate science teachers in their schools making classroom observation difficult.
"Our school does not have enough Physics and Chemistry teachers and the HOD in charge has to teach subjects in schools hence inadequate supervision of teaching of the subject by other teachers."

The lack of regular classroom observation may mean that teachers cannot be able to monitor to check on what they deliver in classrooms whether it conforms to the standards or not. The results agrees with a study conducted by Muyoyeta (2018) who discovered that more learners $(34 \%)$ agreed that the HODs of Science conduct class visits and $30 \%$ strongly agreed while $53 \%$ of the teacher and $47 \%$ of the HODs of Science also agreed with the same statement. However, $33 \%$ of the teachers and $27 \%$ of the HODs of Science disagreed with the statement. This means that classroom visits by HODs of Science appears to be irregular. Results also reveal that HODs of Science agreed that often $(\mathrm{M}=3.60$ and $\mathrm{SD}=0.93)$ they conducting monitoring to ensure effective management and utilisation of instructional resources by teachers and students in classroom. However, science 
teachers said that the process by HODs of Science happens sometimes $(\mathrm{M}=3.05$ and $\mathrm{SD}=1.17)$. This means that not all times do HODs of Science come to class to check whether teachers use the required instructional resources to aid in teaching and learning of science subjects in public secondary schools in Nandi County, Kenya. The result may also mean that some schools have underutilised instructional resources since no follow up is made by HODs of Science to ensure that they are utilised to the benefit of improving students' academic performance in science subjects.

Research result also showed that both HODs of Science $(M=4.36$ and $S D=3.71)$ and science teachers $(M=3.71$ and $S D=1.18)$ agreed that often are department meetings used as platforms for corrective steps aimed at improving quality of teaching and learning in their schools. this means that departmental meetings acts as monitoring and control avenues through which curriculum decisions are made for the purpose of improving students academic performance in sciences. Data result also show that HODs of Science said that planning is often done $(M=4.21$ and $S D=0.83$ ) with teachers on assessing and evaluating the instructional activities for improved performance. However, science teachers appeared to indicate that this joint planning for evaluation and assessment of instructional activities happen on occasional basis $(M=3.38$ and $S D=1.25)$. The result therefore depicts that not all times are teachers involved in planning on how to assess instructional activities in the department to see whether they are performing or underperforming. This act of not being involved in planning might hinder the realisation of departmental goals of improved academic performance in sciences. Research result showed that both HODs of Science agreed that they often $(M=3.94$ and $S D=0.79)$ performed the role of internal curriculum supervisor in their schools. This statement was also supported by teachers who at least said that HODs of Science often ( $M=3.53$ and $S D=1.05)$ act as internal curriculum supervisor in ensuring that standards of curriculum delivery are followed. The act of regular supervising curriculum implementation in classroom lessen the burden of head teachers and deputy head teachers hence improved academic performance in science subjects by students. In line with the study results, Jaca (2013) said that HODs of Science were engaging in discussions with teachers in an attempt to collectively find solutions, substituting absent teachers, taking work home, using the expertise of other teachers through delegation, leading by example by presenting lessons for teachers. I

Study results also showed that HODs of Science agreed that at least on often basis $(M=3.55$ and $S D=1.09$ ) are they involved in organising subject meetings to evaluate teachers capacity to effectively teach their specialised subjects in classroom. Science teachers indicated that this activities is sometimes $(M=3.37$ and $S D=1.09)$ performed by their science HODs of Science in schools. In line with the study results, Mpisane (2015) found out that HODs of Science were involved in holding meetings assists in empowering teachers as they share information and improve their communication skills and enhance their knowledge. In addition, Niyivuga et al. (2019) also found out that HODs of Science in Rwanda schools organised departmental meetings to discuss shortfalls and achievement. Therefore, the result suggests that subject meetings do not happen regularly considering some schools do not teach all the three science subjects at once while others have inadequate number of teachers teaching specific science subjects. This makes it impossible to have subject panel discussions in schools with less number of teachers. Lastly, HODs of Science said that they often $(M=3.07$ and $S D=1.06)$ monitor effective integration of ICT in teaching of science subjects whereas teachers agreed that rarely $(M=2.44$ and $S D=1.03)$ do $H O D s$ of Science in their secondary schools perform this function. This could be due to limited knowledge on ICT by some HODs of Science or negative attitude that some of them may have concerning the usage of technology.

Furthermore, not all schools are endowed with adequate ICT facilities and therefore making the issue of monitoring the utilisation and integration in classroom teaching and learning of science subjects difficult. This information was corroborated by school heads interviewed where Principal No. 23 said that:

"More training is needed for HODs of Science in our schools for ICT skills and its integration in teaching and learning of science."

However, Principal No. 8 said that HOD of science in their institution had the capacity to guide science teachers on ICT integration in teaching and learning. Composite data show that HODs of Science rated their monitoring and control skills as high $(\mathrm{M}=3.72$ and $\mathrm{SD}=0.95)$ compared to teachers who rated their HODs of Science monitoring and control skills as average $(M=3.19$ and $S D=1.11)$. Some principals indicated that HODs of Science capacity to 
monitor and control teaching and learning activities in science was fairly good in their schools while others decried that their HODs of Science lacked adequate capacity for monitoring and control activities. Different from the study results, Ogina (2017) research in South Africa established that HODs of Science talked their role in controlling and checking what the teachers do in class in the light of teaching and learning. They achieved this through monitoring and controlling the teachers' work concerning curriculum implementation through regular classroom visits, sampling learners' work and providing prompt assistance where teachers have problems emerged as components of the role of the heads of department in this study.

A bivariate correlation analysis was computed involving composite scores on ratings of HODs of Science monitoring and control skills against combined performance in Biology, Physics and Chemistry examinations from HODs of Science and science teachers' perspectives. The purpose was to check on the degree of influence of the fourth independent variable on dependent variable. The results of analysis from science teachers are given in Table 5.

Table 5: Correlations on HODs of Science Monitoring and Skills and Academic Performance of Students in Sciences

\begin{tabular}{llll}
\hline & & $\begin{array}{l}\text { Monitoring } \\
\text { Control }\end{array}$ & $\begin{array}{c}\text { and } \\
\text { Academic } \\
\text { Performance }\end{array}$ \\
\hline Monitoring and Control & Pearson Correlation & 1 & $.547^{* *}$ \\
& Sig. (2-tailed) & & .000 \\
& $\mathrm{~N}$ & 223 & 223 \\
\hline Academic Performance & Pearson Correlation & $.547^{* *}$ & 1 \\
& Sig. (2-tailed) & .000 & 223 \\
\hline${ }^{* *}$. Correlation is significant at the 0.01 level (2-tailed). & 223 & \\
\hline
\end{tabular}

The correlation statistics show that at $99.0 \%$ confidence level there exist significant influence of HODs of Science monitoring and control skills $(r=0.547 \& p=0.001)$ and academic performance of students in science subjects in public secondary schools in Nandi County. The correlation values are positively weak suggesting that the monitoring and control activities performed by HODs of Science have not made much more effect on improving academic performance of students in sciences in schools. The statistics however suggests that application of monitoring and control strategies by HODs of Science consistently in their department would result to improved performance of students in science subjects in their schools. This information is supported by Katana (2015) who found out that majority $(77 \%)$ of the respondents agreed that monitoring \& evaluation competencies by HODs of Science influence students academic performance while the remaining $23 \%$ disagreed with this.

Table 6 presents the statistical results from the HODs of Science perspective.

Table 6 Correlations on HODs of Science Monitoring and Skills and Academic Performance of Students in Sciences

\begin{tabular}{llll}
\hline & & Monitoring and Control Skills & $\begin{array}{l}\text { Academic } \\
\text { Performance }\end{array}$ \\
\hline Monitoring and & Pearson Correlation & 1 & $.545^{* *}$ \\
Control Skills & Sig. (2-tailed) & & .000 \\
& $\mathrm{~N}$ & 114 & 114 \\
\hline Academic & Pearson Correlation & $.545^{* *}$ & 1 \\
Performance & Sig. (2-tailed) & .000 & 114 \\
& $\mathrm{~N}$ & 114 & \\
\hline **. Correlation is significant at the 0.01 level (2-tailed). & \\
\hline
\end{tabular}


The results shows that there exist significant positive effect $(r=0.545 \& p=0.001)$ between HODs of Science rating of their monitoring and control practices and academic performance of students in science subjects in KCSE examinations. The result show that there is an above average influence of HODs of Science monitoring and control skills on academic performance in sciences in public secondary schools in Nandi County, Kenya. Through interview, the principals were asked to provide their responses with regard to the contribution of HODs of Science on monitoring and control of instructional activities towards academic performance in sciences. Principal No. 5 recorded that:

"HODs of Science monitoring and control skills are fairly good to ensure improvement in academic performance in sciences."

Another Principal No. 15 said that:

"Through HODs of Science regular monitoring, teachers perform or undertake their duties as expected and any deviation is corrected to ensure improved academic performance in the science by students in schools."

The above responses show the significance of HODs of Science monitoring towards performance improvement in science in secondary schools. However, the principals indicated that HODs of Science needs proper induction on how to conduct monitoring and control activities in their schools.

\section{CONCLUSIONS AND RECOMMENDATIONS}

The research found out that monitoring and control was an ongoing activity that HODs of Science of sciences performed in their institutions. The main activities as reported was that HODs of Science normally encouraged their science teachers to follow lesson plans during teaching of science subjects in their meeting and using departmental meetings as correction centre for improving quality teaching and learning of sciences in schools. However, HODs of Science, principals and science teachers agreed that classroom observation as part of monitoring and control of science learning in schools was rarely done. Follow up on integration of ICT in teaching and learning of science subject was found to be rarely performed by HODs of Science of science in the schools in Nandi County. The fourth null hypothesis was rejected leading to the conclusion that there existed significant positive influence $(p<0.05)$ of monitoring and control on performance of students in sciences. To address monitoring and control practices, TSC needs to improve staffing levels in public secondary schools especially in science subjects. This will ensure that classroom observation and internal curriculum supervision practices are conducted regularly for quality checks and also improved performance.

\section{REFERENCES}

Ambula, O., 2010. Does Free Secondary Education Enable the Poor to Gain Access. A Study from Rural Kenya. Create, 21, 1-14.

Ayiro, L., 2012. Functional approach to Educational Research Methods of Science and Statistics: Qualitative, Quantitative and Mixed approaches. New York: Mellen Press.

Bichi, A. A., Hafiz, H. and Abdullahi, S., 2017. Evaluating Secondary School Students' Science Achievement: Implication for Curriculum Implementation. International Journal for Social Studies, 3(1), 113 121.

Dean, P., 2002. "Long-term factors contributing to teacher wastage:, in A. Ros (ed.), Emerging Issues in Teacher Supply and Retention: Proceedings of the Second Conference of the Teacher Supply and Retention Project, Institute for Policy Studies in Education.

Foskett, N. and Lumby, J., 2003. Leading and Managing Education. London: SAGE Publishing.

Graume, G. and Naidoo, H., 2011. Strategic Planning and performance of secondary schools in Kisumu East District, Kenya. McGraw International.

Jaca, N. I., 2013. The leadership role of the Head of Department in the teaching of Mathematics. Masters Thesis, University of Pretoria, South Africa.

Kweku, B. S., Maansah, P. A. H., Alhaji, Y. S. P. and Obu, L. C., 2016. Assessing the Challenges Heads of Department Encounter in Instructional Supervision in Ghana. A Case of Selected Senior High Schools in Kwabre East District. Journal of Education and Practice, 7(36), 156 169. 
Malinga, C. B. B., 2016. Middle management and instructional leadership: a case study of Natural Sciences' Heads of Department in the Gauteng Province. PhD Thesis, University of the Free State, South Africa.

Mpisane, B. B., 2015. The role of high school heads of department as leaders of learning. Masters Dissertation, University of Kwa- Zulu Natal.

Muyoyeta, N. K., Abah, J. and Denuga, D., 2017. School- Based Factors Affecting Grade 12 Learners' Academic Performance in Namibia Senior Secondary Certificate Ordinary level biology in the khomas educational region, Namibia. International Journal of Education, Learning and Development, 5(7), $9-22$.

Ndungu, B. W., Gathu, A. and Bomett, J. E., 2015. Influence of Monitoring and Evaluation by Principals on Effective Teaching and Learning in Public Secondary Schools in Githunguri District. Journal of Education and Practice, 6(9), $10-17$.

Niyivuga, B., Otara, A. and Tuyishime, D., 2019. Monitoring and Evaluation Practices and Academic Staff Motivation: Implications in Higher Education within Rwandan Context. SAGE Open, 1 - 9.

Nzoka, J. T. and Orodho, J. A., 2014. School Management and Students' Academic Performance: How Effective are Strategies being Employed by School
Managers in Secondary Schools in Embu North District, Embu County, Kenya? International Journal of Humanities and Social Science, 4(9), 86 - 99.

Ogina, T. A., 2017. How Heads of Departments Understand Their Roles as Instructional Leaders: A South African Study. Int J Edu Sci, 18(1-3), 224-230.

Opiyo, S. O., 2014. Influence Of Budgeting On Implementation Of Development Plans In Public Secondary Schools In Uriri District, Migori County, Kenya. MED Project, University of Nairobi.

Rono, K. W., 2017. Effect of Laboratory Management on Students' Performance in Physics In Public Secondary Schools In Bomet County, Kenya.

Seobi, A. B. and Wood, L., 2016. Improving the instructional leadership of heads of department in under-resourced schools: A collaborative action-learning approach. South African Journal of Education, 36 (4), Art. \# 1326, 14 pages, doi: 10.15700/saje.v36n4a1326.

Shonubi, O. K., 2014. How leadership and management dynamics contribute to school effectiveness. PhD Thesis, University of Pretoria.

Zenda, R., 2016. Factors affecting the academic achievement of learners in Physical Sciences in selected Limpopo rural secondary schools. PhD Dissertation, University Of South Africa. 